DOI https://doi.org/10.30525/978-9934-26-004-9-100

\title{
ТРАНСФОРМАЦІЯ ЯК АКТУАЛЬНИЙ НАПРЯМ ДИЗАЙНУ ШКІЛЬНОГО ФОРМЕНОГО ОДЯГУ
}

\author{
Васильєва I. В. \\ дочент кафедри ергономіки і дизайну \\ Гричанюк О. В. \\ магістр кафедри ергономіки і дизайну \\ Калун О. Ю. \\ магістр кафедри ергономіки і дизайну \\ Васильєва О. С. \\ кандидат технічних наук, \\ доиент кафедри дизайну \\ Київського начіонального університету технологій і дизайну \\ м. Київ, Україна
}

Сьогодні суттєво змінюються підходи до дизайн-проектування одягу, актуальною стала концепція співтворчості споживача і дизайнера, яка знайшла своїх прихильників серед багатьох дизайнерів дитячого модного одягу. Серед сучасних тенденцій дизайну актуальним $\epsilon$ прагнення творчого підходу до використання одягу, перетворення його у розвагу, у творчу діяльність, яка викликає позитивні емоції та приносить радість, що особливо важливо для дитячого одягу [1]. Такі можливості закладаються в формах, що трансформуються, в елементах, що приєднуються та від'єднуються, в різних доповненнях і аксесуарах, які можуть замінювати один одного. Трансформація - це перетворення, зміна виду, форми, істотних властивостей чого-небудь, це властивість об'єктів предметно-просторового світу змінювати свої початкові форми і параметри в процесі існування або експлуатації. Згідно з визначенням, можна зробити висновок, що трансформації відбуваються і в процесі носіння за участю людини, і в період всього терміну служби виробу. Одяг, що трансформується, може змінювати свій естетичний вид, призначення та асортиментну групу. Отже, трансформований одяг являє собою рухливу матеріальну структуру (конструктивну і естетичну), що дозволяе йому перетворюватися в вироби різного асортименту або істотно змінювати властивості даних виробів. Проектування предметів 3 
конструкцією, здатної до модифікації, становить один із актуальних напрямів в дизайн-проектуванні сучасного костюма. В цілому процес перетворення (трансформації) одягу і його окремих елементів може носити множинний характер. В цьому процесі $є$ позитивний момент, тому що проектований виріб внаслідок своєї різноманітності і багатофункціональності не набридає i тому термін його носіння продовжується.

Спосіб життя сучасного школяра, технології виробництва одягу, що стрімко розвиваються, і постійна зміна функціональних процесів у житті суспільства є основними причинами появи одягу, здатного задовольнити всі вимоги дитини відповідно різноманітним запитам і потребам. Гардероб дітей і підлітків повинен постійно поповнюватися новим одягом i його елементами. При цьому реалізується бажання використовувати ці речі багатофункціонально (в різних поєднаннях і в різноманітних ситуаціях). Починаючи 3 20-х pp. XX століття проектування багатофункціональних речей стає одним із завдань дизайнерів i конструкторів. Основною метою прихильників даного напрямку дизайн-проектування було створення універсальних речей, які б були здатні задовольнити різноманітні запити людини і дозволяли економити матеріальні ресурси, що $\epsilon$ актуальним 3 точки зору екологічних проблем, які стоять перед сучасним суспільством [1]. Вироби багатофункціонального призначення, що трансформуються, відносяться до модного сучасного одягу підвищеного попиту.

Принципи трансформації мають фундаментальне значення у формоутворенні сучасного предметного середовища і дають практично невичерпні можливості у пошуку нових творчих рішень багатофункціональних форм. Сьогодні під багатофункціональним гардеробом, що утримує потенціал до трансформації, розуміють набір предметів i його частин одягу, які мають єдину композиційну цілісність, і володіють рухливою структурою і формою, що дозволяють їм доповнювати, заміщувати один одного або перетворювати в іншу річ, суттєво змінюючи при цьому їх властивості. У сучасному дизайнпроектуванні одягу 3'явився напрямок мінімалізму, концепція якого полягає в проектуванні одягу, орієнтованого на формування гардеробу, що складається 3 мінімальної кількості багатофункціональних предметів одягу $[1,2]$.

Принципи трансформації, за допомогою яких можна видозмінювати одяг, його вузли і деталі та надавати їм нових функцій, $є$ досить поширеним у проектуванні сучасного одягу для дітей та підлітків. Відомо, що до принципів трансформація, що використовують при 
проектування одягу, відносяться [3]: перетворення однісї форми в іншу (наприклад, зміна довжини виробу, трансформація одного елемента костюма в інший (головного убору в краватку тощо); трансформація деталей всередині однісї форми вироби (наприклад, елементи одягу трансформуються (загинаються, складаються, зав'язуються тощо). Використання шкільного форменого костюму для дітей та його складових елементів, що розроблені на основі принципів трансформації, дає можливість учням та їх батькам самостійно контролювати ступінь комфортності відповідно до зміни розмірних ознак дитини, ситуації та сезону використання, що сприяє проведенню навчального процесу та гармонійного розвитку особистості. При цьому трансформація в одязі зводиться до видозмін деталей готового виробу, перестановки, від'єднання або приєднання начіпних деталей тощо.

Підвищенню задоволення споживчих вимог дитячого одягу сприяє створення виробів, які забезпечують трансформацію за зовнішнім виглядом, формою, призначенням, розмірними характеристиками, призводячи до збільшення термінів експлуатації. Трансформація в цьому випадку виступає, як морфологічна особливість, при якій одяг набуває здатності змінювати свої просторові характеристики, формувати нові властивості та видозмінювати функцію. Сучасний шкільний формений одяг повинен мати потенціал до видозміни зовнішнього вигляду та комбінування. Саме тому прийоми і принципи трансформації мають важливе значення у формотворенні сучасного одягу для дітей і дають практично невичерпні можливості пошуку творчих рішень багатофункціональних форм. Можливість експериментувати, видозмінювати i трансформувати різні предмети або елементи одягу дозволяє школяреві отримувати практично необмежену можливість самостійно моделювати безліч варіантів модного костюма, представляти їх в різних стильових та композиційних рішеннях і завжди мати новий індивідуальний образ [3]. На рис. 1 представлено, як приклад, розбірний багатофункціональний предмет одягу, що являє собою спідницю, яка має начіпні деталі, виконані з можливістю утворення сарафану, рознімно з'єднані з поясом. 


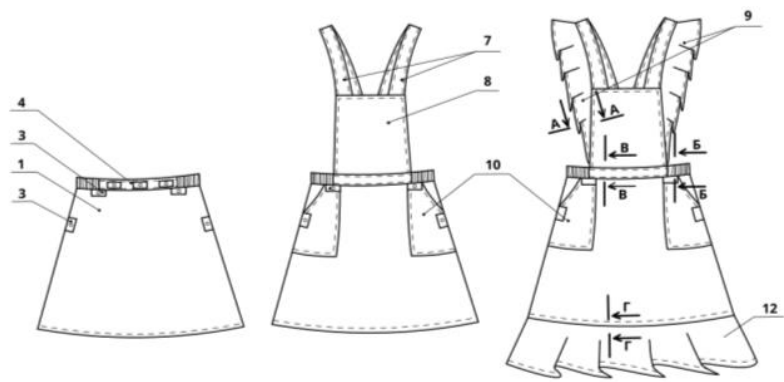

Фir.1

Фir.3

Фir.5
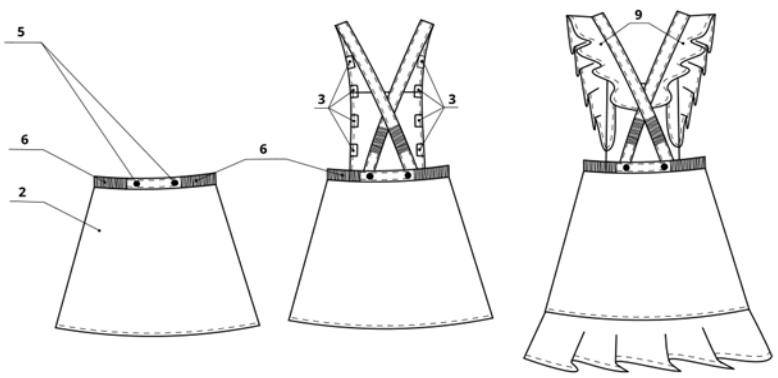

Фir.2

Фir.4

Фir.6

Рис. 1. Розбірний багатофункціональний предмет одягу спідницясарафан: фіг. 1, 2 - спідниця, фіг. 3, 4 - сарафан; фіг. 5, 6 - сарафан 3 крильцми та шляркою; 1-12 - деталі виробу

Протягом тривалого часу були вироблені певні прийоми конструктивно-технологічного та композиційного рішення трансформованою одягу i його елементів. Існуюча класифікація прийомів і методів трансформації предметів і елементів одягу є вихідною інформацією для проектування сучасних трансформованих виробів різного функціонального, ергономічного і естетичного призначення. До існуючих прийомів трансформації відносяться: розтягування стиснення, відділення - приєднання, регулювання - фіксація, згортання розгортання, заміщення, орієнтація, перестановка, компонування, вивертання [4]. В роботі було проаналізовані сучасні моделі дитячого одягу, виокремлено варіанти композиційно-конструктивних рішень трансформації та систематизовано їх відповідно існуючих прийомів трансформації. Також розроблено нові рішення трансформації шкільного форменого одягу. 


\title{
Література:
}

1. Гайдук Л. М., Васильєва І.В. Сучасні технології моделювання і художнього оздоблення одягу: навч. посіб. Київ : КНУТД, 2008. 142 с.

2. Абилкамова К. К. Разработка методики формирования многофункционального гардероба женской одежды на основе инновационных технологий : дис. ... д-ра философии : 6D072600. / Алматинский технологический университет. Республика Казахстан, Алматы, 2018. $145 \mathrm{c}$.

3. Васильєва О. С, Колосніченко О. В., Васильєва І. В., Остапенко Н. В. Розробка класифікації видів і принципів реалізації функції трансформації дитячого шкільного одягу і гардеробу. Теорія $i$ практика дизайну: Збірник наукових праць. Технічна естетика. Київ, «Дія», 2017. Вип. 13. С. 27-41.

4. Остапенко Н. В. Розвиток наукових основ дизайн-проектування захисного одягу з використанням принципу трансформації : дис. ... д-ра техн. наук : 05.18.19. / Київський національний ун-т технологій та дизайну. Київ, 2017. 367 с.

DOI https://doi.org/10.30525/978-9934-26-004-9-101

\section{ШРИФТ ЯК ЕЛЕМЕНТ ДИЗАЙНУ ВЕБ-САЙТА КОМЕРЦІЙНОГО ПІДПРИЕМСТВА}

\author{
Васильєв О. С. \\ аспірант кафедри ергономіки і дизайну \\ Київського національного університету технологій і дизайну \\ Колосніченко О. В. \\ доктор мистеитвознавства, професор, \\ професор кафедри художнього моделювання костюма \\ Киїського національного університету технологій $і$ дизайну \\ Васильєва I. В. \\ дочент кафедри ергономіки і дизайну \\ Київського національного університету технологій і дизайну \\ м. Київ, Украӥна
}

Сучасний бізнес неможливо уявити без новітніх технологій та глобальної комп'ютерної мережі Інтернет. Інтернет-торгівля - це сучасний та відносно дешевий канал продажів, що слугує ефективним доповненням традиційної торгівлі, а в деяких випадках і самостійним 122 